\title{
Housing as urbanism: The role of housing policies in reducing inequalities. Lessons from Puente Alto, Chile
}

Camila Cociña, Research Fellow, The Bartlett Development Planning Unit, University College London, 34 Tavistock Square, London, WC1H 9EZ, UK. Tel: +44 (0) 203108 9496. Email: camila.cocina@ucl.ac.uk

This work was supported by CONICYT-Chile under the programme Becas Chile.

\begin{abstract}
This article explores the potential of housing policies to reduce economic, social, and political inequalities. Understanding inequalities as issues of distribution and recognition, housing policies have the potential to tackle them by encouraging more equal outcomes and processes. Presupposing the centrality of the urban dimension in current debates, this article puts forward the idea of housing as urbanism as a framework of analysis.

This framework is used to discuss the Chilean case, a market-led housing system that is considered as a financial model by many countries in the global South. However, urban shortcomings have encouraged policy makers to incorporate explicit urban equality ambitions in recent years. Based on empirical work conducted in Bajos de Mena, Santiago, the article presents two programmes with equality aspirations, examining their economic, social, and political impacts. In order to draw lessons from the cases contributing to wider debates, it identifies the main challenges in addressing inequality, reflecting on the relevance of these conclusions beyond the Chilean case.
\end{abstract}

\section{Keywords}

housing policy - social housing - inequality - urbanism - Chile 


\section{Introduction}

Housing policies play a central role as drivers of urban development, affecting many of the challenges that define the current urban condition. Housing cannot be mistaken as just a collection of walls and a roof, as it 'is always more than just housing. It provides shelter, but fulfils other functions as well' (Madden and Marcuse, 2016, p.85). Previous literature has focused on discussing some of the 'non-housing' effects of housing policies, including their impacts on fields as diverse as labour markets, education, health, community viability, violence, and income distribution (see Yates, 2012; Bridge et al, 2003; Martin et al, 2015). Arguably, the urban dimension of housing policies, and specifically issues of urban equality, has become a main global challenge, as stated by the New Urban Agenda and its call for building inclusive cities that "leave no one behind' (United Nations, 2017). In this context, this article explores the potential role of housing policies in reducing inequalities, proposing a framework to analyse their urban impacts in this regard.

The question that this research is pursing is what the role of housing policies is in reducing inequalities. Understanding inequalities as issues of redistribution and recognition, housing policies have the potential to tackle them by encouraging more equal outcomes and processes. Assuming the centrality of the urban dimension, it builds upon the idea of housing as urbanism to suggest a framework that links housing and inequalities in economic, social and political terms. As part of this ambitious query, the scope of this article is twofold: on the one hand, it proposes a conceptual definition of housing that can shed light on the debates about urban inequalities; and on the other, it uses the proposed framework to analyse two housing programmes in Santiago, Chile, exploring the extent to which they are contributing to tackling inequalities, and presenting the main lessons and 'cracks' in which housing policies are or could be instruments for such a goal.

Since the late 1970s, Chile has been a paradigmatic case as an early adaptor of the economic and social reforms that later spread globally following the Washington Consensus (Harvey, 2005; Gilbert, 2002; Richards, 1995). In terms of housing, financially effective policies and quantitative achievements, accompanied by poverty reduction strategies considered widely successful, have been considered a best practice and replicated as a model since then (Gilbert, 2002, 2004). However, despite these positive achievements, economic and urban disparities in the country have remained stagnant or even deepened during the same period (López et al, 2013; Güell, 2013; Larrañaga, 2016; PNUD, 2017). 
Some of the noxious urban consequences of Chilean housing policies have been widely researched in the past (Ducci, 2000; Rodríguez and Sugranyes, 2004; Sabatini et al, 2001; Salcedo, 2010; Cociña and Boano, 2013). This critique pushed in 2006 for a housing policy reform that incorporated an explicit narrative of qualitative urban deficit and equality. Considering that in the eyes of policy makers these new housing programmes would address problems in terms of urban equality, it is worth asking if they are actually moving in that direction. This paper articulates a reflection around the post-2006 Chilean case and its equality ambitions. Then, it contributes to the debate about the role that housing policies might have in reducing inequalities, assuming the current centrality of the urban question; particularly, in urban contexts of the so-called global South, many of which have seen in the Chilean case a model to follow, overlooking its consequences in terms of urban equality.

The structure of the article is as follows: It starts by discussing a series of concepts and proposing a framework to link housing and inequalities in economic, social and political terms; the main argument proposed is that housing policies can play a role in reducing inequalities, but to do so housing must be conceived as urbanism, as a process multiple in nature and scale, and inequalities need to be understood in their complexities and diverse dimensions. Then, following a brief context and methodological section, it discusses two housing programmes in Chile. Finally, it presents lessons from the cases, pointing out the key obstacles faced, and identifying some 'cracks' in which housing policies could be instruments to reduce inequalities. To conclude, it reflects on the relevance of these reflections beyond the Chilean case.

Certainly, the questions that this work addresses exceed in complexity the scope of this article. Understanding its limitations, it contributes to a discussion that is based on a normative working hypothesis, assuming that housing policies could do something about inequalities. There is an assumption that our houses, the space where we wake up every morning, the most expensive and durable goods owned by most people, have something to do with the way we experience disparities; that housing, as a spatial body, can play a role as an economic, social and political device. And that urbanism, as an analytical tool, can contribute to explore some of these potentials.

\section{Inequalities, the city and housing as urbanism: A possible framework}

For decades, housing policies in most Latin American countries have been conceived as socioeconomic instruments with direct implications in terms of poverty alleviation (Ramírez, 2002). The understanding of poverty, however, has moved over the years towards more 
multidimensional approaches, embracing aspects of vulnerability and entitlement as part of a cross-sectoral approach (Moser, 1995; Wratten, 1995). As the evolution of ideas about poverty and their translation into policies have moved away from quantitative and mono-sectoral approaches, they start to involve aspects of redistribution and recognition that are at the core of the reduction of inequalities, therefore requiring a different set of approaches.

The displacement of the debate from urban poverty towards urban equality implies to 'begin to unpack political processes within the city' (Stephens, 2012, p. 465). This shift takes place in a global context in which there has been an increase of inequalities within and among countries (UN-Habitat, 2003). Strictly in economic terms, the last century has shown that developing economies are not synonymous with decreasing inequalities (Piketty, 2014; Wilkinson and Pickett, 2009), posing important challenges for socioeconomic policies. In Thomas Piketty's words, "[t]he history of inequality is shaped by the way economic, social and political actors view what is just and what is not, as well as by the relative power of those actors and the collective choices that result' (2014, p.20). In terms of urban debates, the centrality of urban equality has been recognised by international agencies and translated into specific targets, both in the 2016 New Urban Agenda, as in the Sustainable Development Goals.

There are widely discussed differences between the terms inequality and inequity that are important to clarify. In the urban field, inequality is generally used as a descriptive term to refer to actual differences in the access to -or opportunities to achieve- something; while inequity refers to a lack of fairness and therefore to questions of justice (see Stephens, 1996, 2012). Following this tradition, this article uses the term inequality rather than inequity as a way to examine closely actual differences in the economic, social and political realm, understanding that it is only by tackling the combination of these different aspects, that social justice and equity can be achieved. Also, even if inequality is used to describe differences rather than fairness, the article focuses on disparities of both processes and outcomes, as two crucial components of equity.

To explore the potential role of housing, hereinafter this section discusses three fields: inequalities, space, and housing understood as urbanism. Then, a framework proposes a series of potentialities of housing to reduce inequalities, which will be used as lenses to explore the impacts of housing policies in the territory. Rather than a tool to assess quantitative effects, this framework is used to explore the complex relationships that have shaped the capacity of housing programmes to act in the economic, social and political spheres, looking at practices that might explain the paths and effects of policies. In that sense, housing as urbanism recognises the triple condition of housing as an economic, social and political device, seekng to centre the reduction 
of inequalities in the discussion about urban policies, but also to centre the potentials of housing policies in the debates about inequalities.

\section{Discussing inequalities}

Although traditionally inequality has been defined as the problem of income or wealth distribution, there is a rich history of studies focusing on its multiple nature. From a liberal economy perspective, and as a critique of utilitarian equality, the work of Amartya Sen on capabilities was crucial building upon Rawls's (1971) concept of equality of primary social goods, defined as 'things that every rational man is presumed to want' (Sen, 1979, p.214). Then, 'the focus on basic capabilities can be seen as a natural extension of Rawls's concern with primary goods, shifting attention from goods to what goods do to human beings' (Sen, 1979, p.218-219). In his extensive work on this topic, G.A. Cohen discusses the egalitarian principle as 'a policy of rendering the worst off people as well off as possible' (2000, p.15), stating that 'the primary egalitarian impulse is to extinguish the influence on distribution of both exploitation and brute luck' (1989, p.908). According to the sociologist E.O. Wright, a socially just society would be one in which 'all people would have broadly equal access to the social and material conditions necessary for living a flourishing life', that 'does not privilege one kind of capacity over another. These capacities are intellectual, physical, artistic, spiritual, social, and moral' (2013, p.4).

Arguably, inequalities materialise in more areas than the mal-distribution of wealth; we sustain here that only by tackling the combination of economic, social and political inequalities, questions of equity and social justice can be addressed. Considering Nancy Fraser's (1995) approach to social justice, this implies addressing the challenges of redistribution and recognition, understanding social injustices as the combination of economic mal-distribution and cultural misrecognition. If we define inequalities in economic, social and political terms, we could argue that the first encompasses disparities in the distribution of resources, the second in terms of exercising rights and accessing services, while the last ultimately involves the misdistribution of power. Even if the base of power can take multiple forms, wealth has been historically the de facto base of power (Dahl, 1957); and as such, it is very difficult to challenge power if wealth is not redistributed.

The specific relationship that we want to propose is as follows: the reduction of economic maldistribution is necessary to initiate a process of reducing inequalities, but it can only be sustained and intensified over time if it is accompanied by the reduction of social and political inequalities, involving aspects of recognition and power distribution. These processes should trigger cultural and political transformations that support the long-term consolidation of 
economic redistribution. Without these social and political aspects, inequalities might deepen again over time.

\section{Space and urban inequalities}

These various dimensions of inequality do not take place 'nowhere', they are spatially situated in territories that materialise and qualify disparities. As this reflection focuses on housing, the production of cities becomes not just a background where inequalities take place, but an integral part of their reproduction. This implies an understanding of the interconnection between the structure of the space and social transformations, as two entities that influence each other. Or, as Harvey puts it, 'spatial form and social process are different ways of thinking about the same thing' (1973, p.26). Soja points out that justice 'has a consequential geography, a spatial expression that is more than just a background reflection or set of physical attributes to be descriptively mapped', as 'these consequential geographies are not just the outcome of social and political processes, they are also a dynamic force affecting these processes in significant ways' (2010, p.12). This implies that the planning and policy tools available to intervene in the space have consequences in the social order, through either emancipatory reforms or oppressive control (Yiftachel, 1998).

Susan Fainstein's work has focused on the relationship between social justice and the city (1999, 2010), distinguishing the problem of just processes and just outcomes. It is interesting to look at the relation between Fainstein's categories and Fraser's understanding of social justice as a redistribution and recognition problem. A planning system that focuses mainly on just outcomes would have the redistribution question at the centre of it; likewise, those approaches focusing on just processes would be rather centred on questions of recognition. In the same line, and building upon the work of I.M. Young, Fraser and other scholars, Levy and Dávila have discussed spatial inequalities defining socio-environmental justice as 'comprising the three intersecting principles of redistribution, reciprocal recognition, and parity political participation' (2017, p.41).

As with the redistribution and recognition dilemma, we argue that the same logic can be applied in the dichotomy between just outcomes and just processes. In other words, in the production of cities a focus on outcomes that contribute to the redistribution of wealth is necessary to initiate a process of decreasing inequality, but if those outcomes are not accompanied by just processes that trigger recognition, the redistribution achievements will hardly be sustained and deepened.

Here, we propose, is where housing policies can play a role; they can contribute to reduce economic inequality through the redistribution of economic assets, but they also have the 
potential to reduce socio-political disparities, and therefore to strengthen and make sustainable the reduction in inequalities.

\section{Redefining housing as urbanism}

To understand better these multiple potentials of housing, it is indispensable to consider the urban dimension. The framework we propose is rooted on the notion of housing as urbanism, as an analytical and potential political tool. This concept has been used in the past at least by Goodchild, defining it as an idea 'concerned with living conditions, with the physical form of housing, with the management of urban growth and sometimes the management of urban decline' (2008, p.3); and also by Fiori et al to distinguish a generation of policies that has developed 'urban projects with a strong sense of the city and of the urban condition' (2014, p.8). Building upon these ideas, in this article we stretch the idea of housing as urbanism looking specifically at the economic, social and political potentials of housing, using urbanism as a lens. As such, housing is understood as the set of efforts put together to provide homes, which include the private space as well as infrastructure and services, and the socio-political relations built alongside it, with agency at the economic, social and political spheres: housing understood as a material realm, a social position, and a political device.

The challenge of urbanism has been defined as 'how to address the encounter and coexistence of different and often contradictory logics of city-making' (Fiori and Brandão, 2010, p.190). The role of urbanism lies precisely in coordinating efforts and policies working at different urban scales and disciplines. Understanding housing as urbanism implies then recognising the different scales, processes and logics that it encompasses, that can be summarised by three main features described below.

First, housing is both a right and a complex land market. As Aalbers and Christophers explain, '[t]he - literally - vital imperative of housing to social reproduction helps explain, in large part, the persistence and power of the discourse of a "right" to housing, as opposed, pointedly, to the "right" to buy and sell it' (2014, p.381). The condition of right puts housing in the sphere of public interest, and then in potential tension with the logics of land and housing markets. According to Wallace and Williamson, land markets are complex systems that can be described by three components: land, as territoriality; land rights, as the legal status; and land as a complex commodity, in which the cognitive capacity of market participants represents 'the ability to trade in rights in addition to land itself (2006, p.125). This notion of complex commodities allows developing links between the underlying definitions of housing and land as both rights and markets. 
Second, housing has multiple scales. What is the scope and impact of housing production? Housing is a means of city production that affects multiple scales: from the very intimate sphere of home (see Rapoport, 1995; Blunt and Dowling, 2006), to the kind of socio-spatial relations that we build as a society through the order of the city. Housing projects embrace processes that are multidimensional and multiscalar, as they are not just about building individual units, but about shaping neighbourhoods, bringing infrastructure, consolidating communities and therefore producing cities. The articulation of multiple scales through housing poses important challenges to its production, as it requires us to understand that housing, as a process, has a 'footprint' (Fiori, 2014) that exceeds the physical boundaries of the house.

And third, housing is a multidimensional process. The notion of housing as a process rather than an object, as a verb rather than a noun, was introduced more notably by Turner (1976), arguing for an understanding of the value generated through informal processes of housing construction: the production of housing involves individual and collective exercises of creation of value. These notions have been central in the approaches to housing for decades, influencing debates and programmes both in academia and international agencies (see Burgess, 1992; Fiori and Ramírez, 1992; Frediani, 2009). Nowadays it is impossible to dismiss the idea of process in the design of housing policies that have greater ambitions in their goals. Such a process involves questions about design, community engagement, value creation and adaptability, articulating a political project at multiple urban scales.

\section{Bridging inequalities and housing: A possible framework.}

Based on the debates discussed, we propose a series of conceptual bridges (figure 1) that describe potential ways in which housing production can contribute to decrease inequalities. Policies have the potential of reducing economic inequalities, understood as material disparities, if housing becomes a productivity trigger and an asset, increasing the productivity capacity and asset base of families and territories. Housing policies can reduce social inequalities, defined as disparities in the exercise of rights and access to services, if they are understood as a platform to the city at multiple scales, increasing access to the collective resources that the city should bring. And policies have the potential to tackle political inequalities, understood as the access to collective power if housing is recognised as a multidimensional process, fostering the creation of political power, strengthening reciprocal recognition processes and democracy. 
Figure 1. Housing as urbanism: Bridging housing and inequalities.

Source: author.

INEQUALITIES

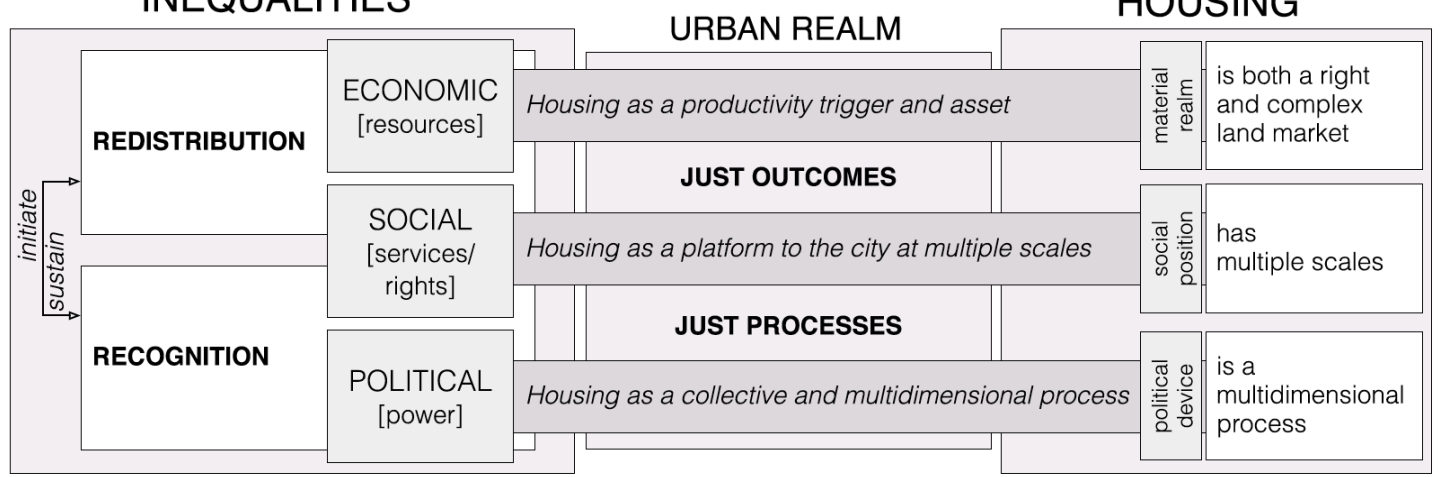

Economic inequalities: Housing as a productivity trigger and an asset. Probably the most evident way in which housing policies can contribute to decreasing material inequalities is by triggering production, at the macroeconomic and households' levels: through either subsidies, land titles or loans, housing policies introduce liquidity to the market and transfer capital to families. This relationship has been widely explored by Harvey's work, studding the role of urbanisation in capital circulation, pointing out that as the creation of value during the housing process is not always even, it can foster surplus redistribution or concentration patterns (Harvey, 1973; 1982; 2008). An additional approach to housing as an instrument for decreasing economic inequalities is the understanding of it as an individual and a collective asset. According to Moser and Dani, housing can be defined as 'often the most important productive asset of the urban poor' (2008, p.24), and as an insufficient but necessary good to increase productivity of other assets. In economic terms, the idea of housing as an asset can be summarised as the capacity of houses to store value during their lifetime, playing a key role in capital circulation (Aalbers and Christophers, 2014). Understanding housing as an asset rather than a fixed good implies an approach recognising that 'assets can enhance the effectiveness of public policies in achieving social and economic development by increasing the capability of people to strengthen their asset base, obtain higher returns on their assets, and attain more secure livelihoods' (Moser and Dani, 2008, p.3). This implies approaching the design and production of housing from a perspective in which it is not a fixed good, but one that may be transformed and changed to be activated as an asset that increases its value, increasing therefore the economic agency of urban dwellers.

Social inequalities: Housing as a platform to the city at multiple scales. Social inequalities are understood as the lack of equitable capacity to exercise rights, accessing to the collective social resources of the city. These disparities emerge from conditions that include socioeconomic, age, gender, and overall class differences. Urbanisation patterns can impact inequality and exclusion, and housing policies can act as instruments either to reinforce or to challenge these processes, particularly 
through the strengthening of segregation patterns (Wacquant, 2008; Madanipour 2007). The negative effects of segregation have been conceptualised by various authors through different mechanisms, including the ideas of 'neighbourhood effect' (Sampson et al, 2002) and geography of metropolitan opportunities (Galster and Killen, 1995). The location within the city has consequences in multiple arenas: ${ }^{\circ} T$ he poor location of housing may, for instance, increase commuting times and hamper access to good schools, clean air, transportation and a wide range of other services, recreational and commercial spaces, and so forth' (Aalbers and Christophers, 2014, p.380). Understanding housing as a platform to the city recognises its role in providing and facilitating access to services and urban rights, as a key to tackling social inequalities. This returns to questions of the right to the city (Lefebvre, 1996; Harvey, 2008), and the role of housing in the construction of such an indivisible right.

Political inequalities: Housing as a collective and multidimensional process. Housing has both emancipatory and oppressive potential, and therefore it is a deeply political project. As described by Madden and Marcuse, "[t]o say that housing is political is to say that struggles over dwelling space are inextricable from conflicts over power, resources, autonomy, and agency' (2016, p.87). The political potential of housing translates into at least two issues: firstly, the process of housing production opens the possibility of increasing capabilities; based on the seminal work of Sen, capabilities are defined by people's abilities and opportunities to achieve the things that they value, which can be operationalised 'focusing on resources and their transformation into achieved functionings' (Frediani, 2010, pp. 178); defined as such, capabilities can be of an individual or collective nature (Frediani, 2009). Secondly, housing production can influence processes of conflict and democracy; Miessen (2010) and Swyngedouw (2010) have discussed the potential productive nature of conflict in urban processes, based on the work on political theory of authors such as Chantal Mouffe, understanding that through conflict resolution different voices can play a role in the process of urban production. For housing production processes, this requires challenging static notions of communities and collectives, as "community" has often been viewed naively, or in practice dealt with, as an harmonious and internally equitable collective' (Guijt and Shah, 1998, p.1). These challenges require returning to questions of housing exchange and use value (Turner, 1976), and particularly how the latter can play a central role in the design of policies that trigger collective processes of value creation, capabilities strengthening and empowerment.

The challenge of urban equality is imperative in most countries and particularly relevant for urban context located in the global South. The proposal of three bridges summarised in figure 1 constitute a theoretical exercise, but also an effort to recognise practical potentialities and 
challenges for housing policies that are more ambitious in their scope, and that put at the centre of their concerns the global and local challenge of urban equality.

\section{Bajos de Mena in the context of Chilean housing policies}

As discussed, Chilean housing policies are paradigmatic for a series of reasons: they are not only a relevant model for countries in Latin America and other regions, but they are also facing a particular conjuncture in which urban equality is becoming a key policy and political feature. In the late 1970s, during Augusto Pinochet's dictatorship, Chilean housing policies were transformed towards a 'capital housing subsidy model' (Gilbert, 2004) leaving in private hands the management, construction and capitalisation of profits of social housing production, while residents become house-owners through state subsidies. In a sense, while distributional decisions remained in the hands of the state through the management of subsidies, most spatial decisions were left in the hands of private agents. This scheme, incremented during the 1990s, has allowed the building of thousands of units, dramatically reducing the number of families with housing needs (Salcedo, 2010).

There are a series of particularities of the Chilean social housing model that need to be pointed out: first, as said, the construction of housing is mainly managed by the private sector; second, it is a centralised financial system managed by the Ministry of Housing and Urbanism through regional services, in which the main instruments available are demand-subsidies or vouchers; third, it is based on house ownership, with no existence of public housing, and in which rental schemes using a voucher-like system have been recently introduced but are still not significant in terms of volume; and finally, since the early 2000s, the beneficiaries of subsidies from the most vulnerable groups need to have savings, but housing is provided without the requirements of loans.

Bajos de Mena: Stigma and precariousness in the outskirts of Puente Alto

As mentioned above, the quantitative housing achievements are contrasted by important criticism to the socio-spatial and segregation consequences of the privatised voucher-based model. One of the most significant consequences has been the construction of socially and functionally homogenous neighbourhoods in the peripheries of cities, with low quality housing construction, poor connectivity, and high levels of overcrowding, stigmatisation and violence. Bajos de Mena (BdM), located in the outskirts of the district of Puente Alto in Santiago, is one of 
the most emblematic of these neighbourhoods, and its history has become the paradigm of a failed way to produce housing.

Since the beginning of the 1990s, thousands of housing units have been built there, most of them subsidised by the state and built by the private sector without any urban plan underlying. The sector lacks most facilities or public infrastructure ${ }^{1}$, and is surrounded by a series of physical barriers leaving thousands of families sharing just one main connection with the rest of the city. Internal networks of assistance and dependency are crucial, in which community leaders or dirigentes $^{2}$ act as an indispensable support for a range of local needs, facilitating the access to economic, health or administrative support of residents (Cociña, 2016). With an estimated population of 130,000 inhabitants, and constituted by 49 different neighbourhoods, it has been called the biggest ghetto of Chile (Atisba, 2010). However, the word ghetto is one-dimensional, it stigmatises and creates a forced identity, and it is important to contest homogenising constructions, exploring instead the range of inequalities lived in the territory.

\section{Two housing programmes: Methodological approach and description}

This article focuses on two housing programmes and their implementation in BdM; as discussed, both cases are post-2006 programmes, and therefore incorporated elements of urban equality in their objectives and narratives. The programmes are the Basic Housing Programme DS49 and its implementation in the neighbourhood Jesús de Nazaret, and the Second Opportunity Programme and its implementation in the neighbourhoods of Francisco Coloane and Cerro Morado. While DS49 involves continuity of the traditional policies of production of new houses, the Second Opportunity represents a new kind of intervention in the territory, based on the demolition of housing stock and the provision of subsidies for the owners.

For this research, each neighbourhood was analysed in terms of the impacts of the programmes on reducing inequalities; the main focus was on looking for different voices to understand the power and spatial dynamics behind the interventions, and the ways in which lived inequalities are displayed in the territory in everyday life. This focus serves to bring to light the economic, social and political logics that housing policies are triggering. Empirical work was conducted between 2014 and 2015, which consisted mainly in a combination of four kinds of activities: site visits to

\footnotetext{
${ }^{1} \mathrm{BdM}$ is located $20 \mathrm{~km}$ away from the centre of Santiago, and many residents - particularly women - spend their lives practically without leaving the perimeter of BdM. By the time of this research, there was neither a police station nor a fire station, and there are just basic facilities such as local medical centres, schools, sports facilities, churches, some community centres and minor grocery shops. In 2013, a park was built in the sector of La Cañamera, covering an old landfill site.

${ }^{2}$ Dirigentes is the name given to official community leaders. Dirigenta(s) is the female form of the word Dirigente(s).
} 
$\mathrm{BdM}$, where interviews, mapping and participatory observations were conducted; meetings with authorities and professionals from public institutions, at local and national level; attendance to official activities related to the programmes; and the collection of secondary data from public institutions and the market. More than 30 in-depth interviews with authorities, practitioners and community leaders were conducted.

Figure 2. Santiago, Puente Alto and Bajos de Mena.

Source: author.

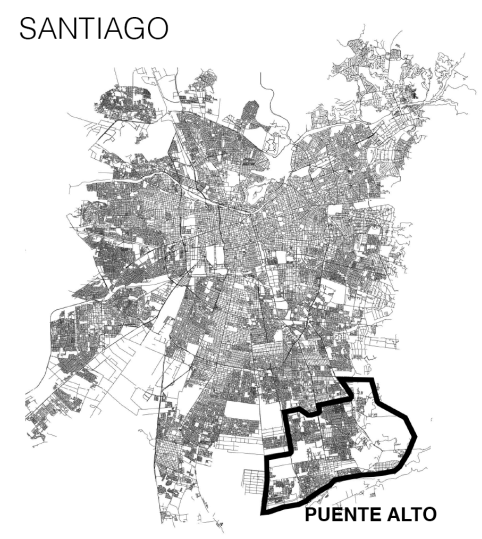

PUENTE ALTO

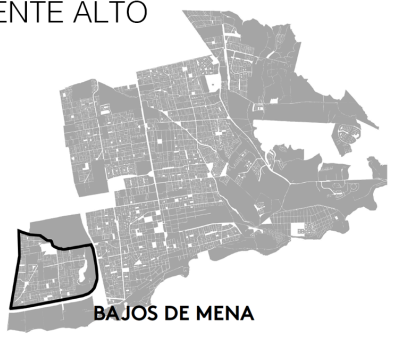

BAJOS DE MENA

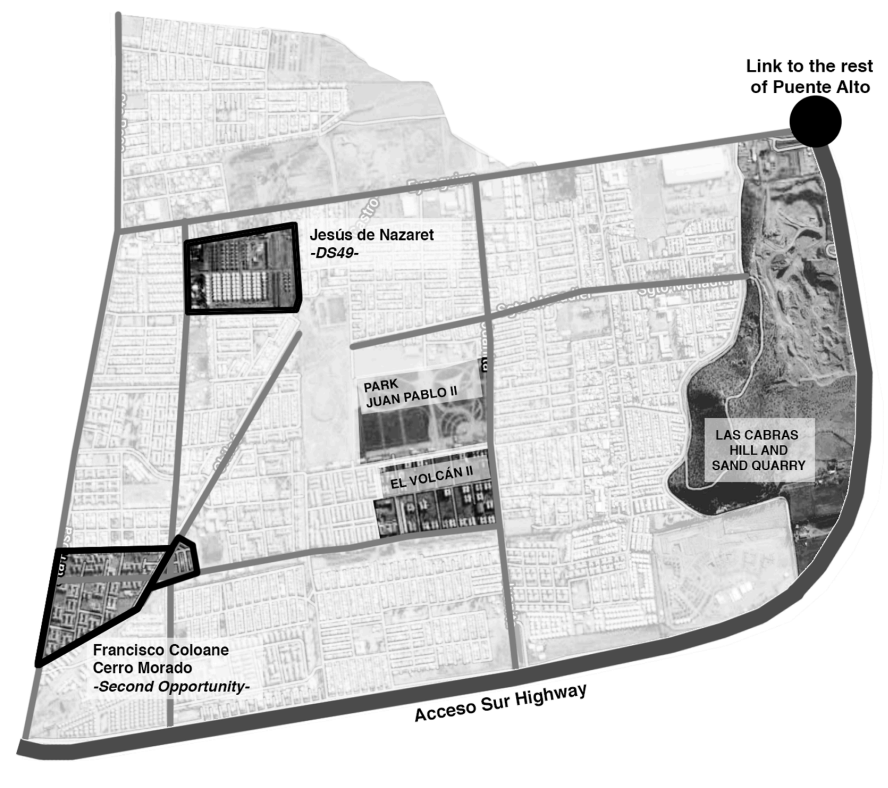

The DS49 programme provides subsidies to poor families, usually in the first quintile. The programme allows people to buy new or used houses and to build houses in either densification or extension schemes. The base subsidy is $380 \mathrm{UF}$ and this can be increased up to $950 \mathrm{UF}^{3}$, if complementary subsidies are used. Jesús de Nazaret is a neighbourhood built in 2014-2015 in what used to be an empty plot at the north of BdM. The neighbourhood is composed of 547 two-storey, semi-detached houses, each with a floor area of 55.6sqm. Even if individual demandside subsidies or vouchers were used, the houses were allocated collectively to people from five different housing committees that had worked together for more than ten years, all from Puente Alto, most of them from BdM, and in which 85 per cent of the members were women. 221 families, more than 40 per cent, came from the infamous and stigmatised area of El Volcán

\footnotetext{
${ }^{3} \mathrm{UF}$ (Unidad de Fomento) is a Unit of account used in Chile; most subsidies and housing prices are indicated in this unit. It is constantly adjusted for inflation. Its value by September 2017 is CL $\$ 26,610$, approximately $£ 32$. In September $2017,380 \mathrm{UF}=£, 12,349$ and $950 \mathrm{UF}=£, 30,872$
} 
within BdM, that since 2008 has been in a process of demolition due to problems in the quality of the construction.

The Second Opportunity, on the other hand, looked to revert processes of degradation in existing neighbourhoods. Differently than previous programmes of neighbourhood regeneration, the Second Opportunity took a very dramatic strategy: removing families from vulnerable areas, and literally demolishing the housing blocks that the state had built less than two decades before. The programme was implemented as a pilot in 2013 in social condos located in 4 districts in the country4; one of the pilot cases was in BdM, in the neighbourhoods of Francisco Coloane and Cerro Morado. Within the designated areas, groups of property owners in the same building could voluntarily join the programme if 95 per cent of the owners in a block agree (MINVU, 2013). Based on an official appraisal of the properties, the state bought the apartments through an expropriation, adding a top-up subsidy to make 700 UF. ${ }^{5}$ In addition, those who inhabited the property received a $46 \mathrm{UF}^{6}$ voucher for the transfer. Once the subsidies were assigned the blocks were emptied, and then SERVIU (Regional Service of the Ministry of Housing) was in charge of the demolition. ${ }^{7}$ Because during its implementation in 2013 it was a voluntary process, the development of the empty plots after was decided case by case and did not relate to an urban plan. To date, all the plots of demolished buildings in BdM are either empty or awaiting to finish the demolition. The destination of the removed families was not part of the programme, and residents of the neighbourhood who did not join the demolition scheme were not considered 'beneficiaries' of it.

In BdM a total of 420 families in 18 blocks joined the programme of demolitions during the first call, 13 of them in Francisco Coloane and 5 in Cerro Morado. According to the official data, out of the 364 beneficiaries whose destinations have been followed, 98 per cent of them stayed in the Metropolitan Region. Within Greater Santiago, 76 per cent of the beneficiaries stayed in Puente Alto, and 42 per cent of the beneficiaries who obtained subsidies stayed in BdM, just moving from one neighbourhood to another.

\footnotetext{
${ }^{4}$ The four areas of the pilot implementation of the Second Opportunity programme are: the neighbourhoods Nuevo Horizonte II and Brisas del Mar, in the city of Viña del Mar; the neighbourhood Vicuña Mackenna, in the city of Rancagua; the neighbourhood Parinacota, in the district of Quilicura in Santiago; and the neighbourhoods Francisco Coloane and Cerro Morado, in the district of Puente Alto also in Santiago.

${ }^{5}$ In September 2017, 700 UF $=£ 22,748$. The owners can decide to give up the subsidy and get the amount of the expropriation in cash if they want to buy a property outside the SERVIU (Service of Housing and Urbanism of the Ministry of Housing) system, and they are forced to receive just the expropriation amount without the extra subsidy if they own a second property somewhere else.

${ }^{6}$ In September 2017, $46 \mathrm{UF}=£ 1,495$.

${ }^{7}$ The only legal instrument of the programme is a five-pages document (MINVU, 2013) that allows families to access public subsidies for a second time during their lives under certain conditions. Therefore, it needs to use instruments from the existing policy tools, namely, the expropriation law that has existed since 1978, and the housing subsidies provided by the DS49, the standard programme for the provision of vouchers for purchasing social housing.
} 


\section{The impact of two housing programmes in Bajos de Mena: Analysis and discussion}

Using the framework previously discussed, this section reflects on the impacts of the DS49 and Second Opportunity and their capacity to be conducive to reduce economic, social and political inequalities.

\section{Economic inequalities}

Are these policies contributing to the capacity of housing to act as a productivity trigger and asset? In absolute terms, both programmes increase the household capital base. For those moving to Jesús de Nazaret, either they did not have a property before or they owned a highly devalued property in El Volcán. In the case of the Second Opportunity more than 85 per cent of the families received $700 \mathrm{UF},{ }^{8}$ which is a clear increase in the capital held in their homes, considering that the original houses where they lived had a value of $227 \mathrm{UF}^{9}$ when they were built in the 1990s (Sandoval, 2005). But the question is whether this increase of capital for the families can be defined as an investment used by the state for redistributive ends, and how effective this investment has been. For both programmes, the investment cannot be seen in isolation from the history of housing investments made by the state in those families. In the case of Jesús de Nazaret, more than 40 per cent came from El Volcán and had gone through a series of publicly-fund housing interventions before, and in the case of the Second Opportunity, the construction and demolition of their original houses is part of the history of housing investment made for those families. As one of the government officials of SERVIU pointed out 'there are 17 years of different decisions; many vouchers, some people moving to other houses in the same area or somewhere else, etc.'

The question is whether this series of investments improve the material conditions of households in relation to the rest of the society. An important factor to consider is that one of the main costs of housing production is associated with land acquisition, and the costs saved by private developers building on cheap land, are ultimately paid directly or indirectly by the families who inhabit the area, diminishing their relative position to other urban households inhabiting better connected areas. In the case of Jesús de Nazaret, the main priority for most families was to leave their previous conditions, even if they remain in a similar location with similar land value. As one of the community leaders said, 'it never occurred to me to leave BdM; for me the issue was to leave El Volcán, and move to a house, not a flat'.

\footnotetext{
8 In September 2017, 700 UF $=£ 22,748$. The rest of the beneficiaries only received an expropriation amount, with values between 403.62 UF and 624.25 UF. In September 2017, 403.62 UF $=£ 13,116$, and 624.25 UF $=£ 20,286$.

${ }_{9}^{9}$ In September 2017, 227 UF $=£, 7,377$.
} 
For the Second Opportunity, more than 42 per cent of the families stayed in within BdM. They faced an important challenge as the implementation of the programme and the use of vouchers created a new market in the area, increasing prices in the surrounding neighbourhoods and affecting affordability. A professional from the programme explains:

There is a process of speculation; (...) people get around CL $\$ 18$ million for the expropriation and subsidy, and that has increased the prices. At the beginning, the houses around the demolition were about CL $\$ 11$ million, and now those houses are sold for CL $\$ 20-25$ million.

Looking at market prices in the area in January 2014 and June 2015, there were gaps between the subsidy value and the property prices of up to CL $\$ 8 \mathrm{M} .{ }^{10}$ In practice, just two of the 36 offers observed had values below the amount of subsidy available, so the beneficiaries of the Second Opportunity would need to use their savings or access to a loan in order to afford any of these properties.

In order to understand whether these investments improve the relative conditions of BdM dwellers, another important element to look at is their impact in terms of livelihoods. Markets or ferias libres are probably the most significant productive unit in the territory, as spaces of social and commercial exchange, with many people working as informal sellers. ${ }^{11}$ The network-based and informal economy is very relevant for understanding the housing decisions of BdM residents. Many residents depend on networks of assistance, sporadic jobs or informal recycling practices. Housing materials and construction skills play a crucial role in the networked and precarious economy of the households. For Jesús de Nazaret, most families took with them elements that could be re-used in the new houses. The fact that they were moving from flats to houses with a garden allowed them to envision future transformations of the houses in a much more secure and sustainable way: 'I brought everything from my flat in El Volcán: windows, frames, fences, everything I had put there, to use it all here', a resident comments, encouraged by the adaptability of the new houses.

The case of the Second Opportunity is slightly more complex. The process of leaving and dismantling the houses is a key event in the implementation of the programme, in which many tensions arise, and families take out all the construction materials and assets they have put in their houses: doors, pipes, copper wires, and even wooden trusses to sell them in the informal market. Probably the most serious economic consequence of the application of this programme for the

\footnotetext{
${ }^{10}$ In September 2017, \$CL\$ 8M = f,9,769.

${ }^{11}$ This does not consider networks of production and trade of illegal drugs, which play an important role in the economy in some networks within BdM, but the volume of which is hard to estimate.
} 
people in $\mathrm{BdM}$ was the absolute absence of any logic of territorial economy, leaving the families who stayed $\mathrm{BdM}$ under the same precarious conditions or even worse ones.

In general, common considerations encountered in the analysis are the fact that the exclusively voucher-based approach makes it difficult to tackle complex economic issues, such as the strengthening of livelihoods and the configuration of productive territories; also, treated as commodity markets, official housing interventions impact on the local real estate market, affecting the affordability of land for residents. The increased home ownership has a positive impact as an individual economic asset, but this does not ensure an improvement in relative terms given that the programmes overlook land and livelihood dynamics.

\section{Social inequalities}

Are these policies contributing to the capacity of housing to act as a platform to the city? Given the problems of social and functional integration in $\mathrm{BdM}$, it is not surprising that the level of dependence on the rest of the city is very high. But at the same time, the rest of the city is seen as something distant and strange. Residents, particularly women and children, would look surprised to know that someone comes from somewhere 'outside Puente Alto district', and therefore the capacity of the territory to answer to social needs is key.

For Jesús de Nazaret, the change of location within the BdM area can have positive impacts. In the case of the families that moved from El Volcán this is clear in many respects, they moved to a much better location within BdM, with less stigma and better transport connectivity. On top of this positive change, it is worth asking to what extent the new neighbourhood produced a more integrated city, conceiving land as a social asset in which common value can be created. Beyond some secondary green areas and a community centre, the neighbourhood can be considered as functional and socially homogenous as the rest of $\mathrm{BdM}$, without any effort to build a different reality. Even if 547 houses is a less dramatic case than others described by authorities with more than 3,000 units, BdM is already known for its problems in terms of social and functional homogeneity, and therefore the challenge of service provision should be at the core of the neighbourhood design -but it is not.

For the Second Opportunity, according to those who worked in the design and implementation of the programme, the idea of an urban master plan was central when it was conceived, but a series of institutional and political factors implied that the execution of it lacked any kind of urban vision. The scenario after the demolitions is basically a patchwork of empty plots, blocks still 
occupied, and blocks half-dismantled but half occupied (figure 3). The voluntary nature of the programme implied that it was not possible to elaborate any kind of design in terms of land use.

Figure 3. Landscape in Francisco Coloane and Cerro Morado after demolitions, 2015. Source: author.
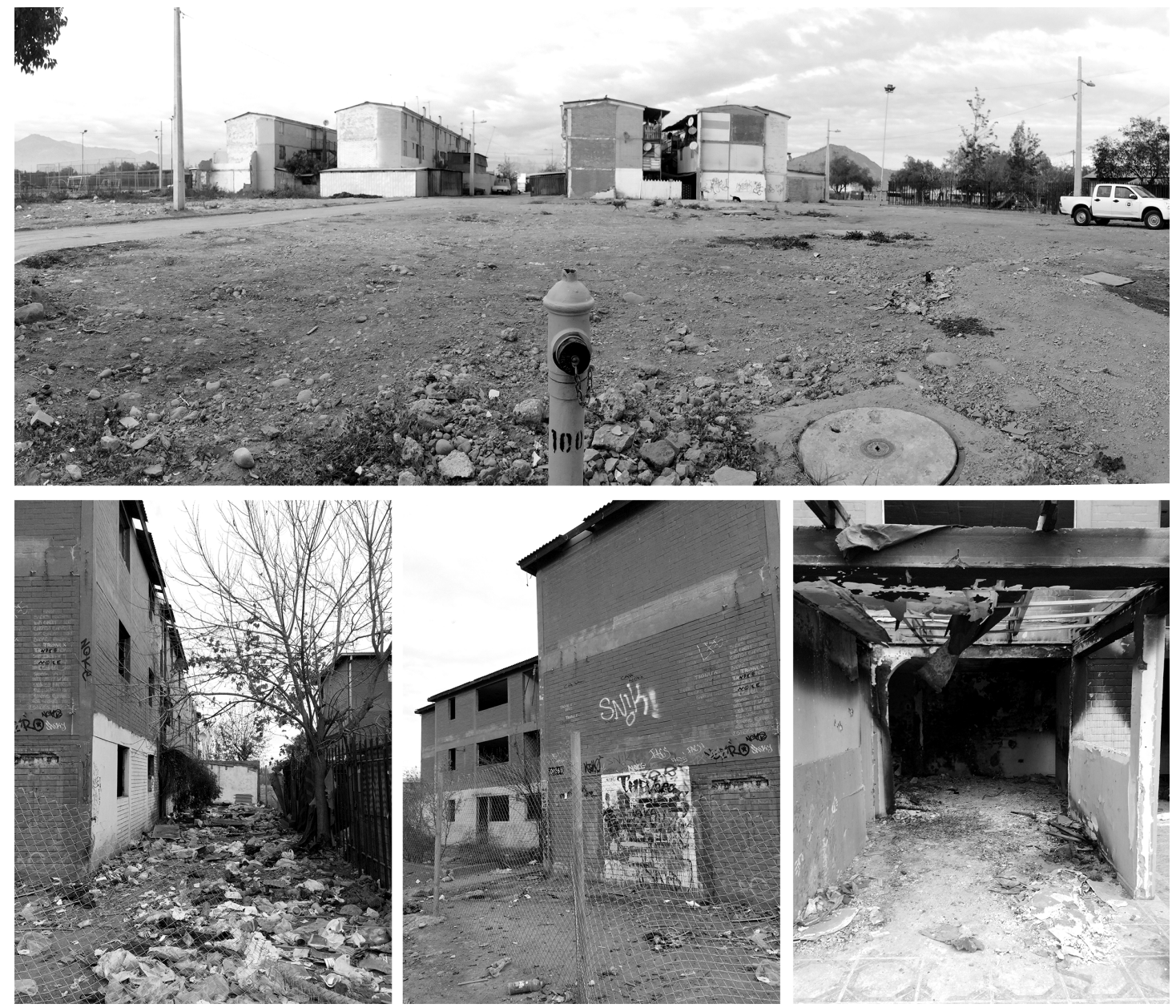

The idea of housing as a platform to the city is intimately related to the capacity of housing to build an environment able to trigger a way of living in which rights can be fully experienced, reconciling gender perspectives, the balance between private and public life, and neutralising the effects of violence. These dimensions directly affect the collective experience of living together. The histories of precariousness in BdM start inside the family, with overcrowded houses and broken bonds. Women usually refer to how the children are at the core of these tales, protecting those who turn good, taking care of those who are lost, and finding ways to stay close to grandchildren, directly affecting their housing decisions. For the beneficiaries of both programmes, their intimate family history, as well as the levels of violence and insecurity in their neighbourhood, directly affected the decisions they took. 
For Jesús de Nazaret residents, it is very explicit that the 'bad times' had been left behind, and with them, the 'bad people'. In that sense, the dirigentas were very emphatic about the fact that there were no gangs' members among the families that moved to Jesús de Nazaret. From the perspective of some of the professionals in the area, however, this is a very brave distinction to make, as these networks are very much part of the social fabric, and drawing a line in binary terms is unreal. For the Second Opportunity, the institutional perspective put all the attention on the families that were leaving, literally leaving behind those who were staying, dealing not just with the unsolved problems of violence, but also with more precarious physical conditions.

In general terms, it is difficult for both programmes to articulate different territorial scales of action, providing services and a systemic understanding of the neighbourhood and city, as they are treated as a financial system based on individual voucher provision. There is a general lack of institutional tools for addressing issues such as land management and the increase of rights, and to look after the complex social fabric and networks of dependency and assistance present in vulnerable territories.

\section{Political inequalities}

Are these policies contributing to the capacity of housing to act as a collective process? Before discussing the effects of these programmes, it is important to acknowledge that in BdM we find important networks of clientelism and non-programmatic politics (Stokes et al, 2013), or what Auyero (2001) has called 'poor people's politics'. Clientelism is based in the existence of patrons (authorities), clients (citizens) and brokers. Dirigentes play a key role as brokers, articulating informal networks that allow traditional political structures to be active in territories (Arriagada, 2013). Relations of clientelism are paradoxical, as they can be defined as asymmetric, but also as mutual interest relationships, and even though they may be based on mutual interest or domination, they are also based on affective and emotional ties (Durston, 2005).

The construction of Jesús de Nazaret was not exempt from these dynamics. The fact that this is a politically contested territory strengthens the historical rivalries between different public institutions managed by opposing political parties. In community meetings officials and residents would refer repeatedly to their gratitude to different authorities, reinforcing the idea of ownership of the projects (or even neighbourhoods) by different authorities.

For the Second Opportunity, the politically contested nature of the territory implied an extraordinary pressure to deliver fast results, and the networks of clientelism exacerbated tensions. The identification of some dirigentes with the 'demolition agenda', deepened by the fact 
that the programme required 95 per cent acceptance in each block in order to proceed ${ }^{12}$, put a lot of pressure on those who did not want to leave, even triggering episodes of intimidation and physical violence against the properties. There were 'sides' in the territory ('war in the blocks', as one interviewee said) in which one of the sides had all the power to extort the other. The fragmentation of the already fragile social fabric diminished the capacity for creating collective social and political capital.

This burden was deepened by the limited understanding of participation of the programmes, sometimes reduced to a list of procedures and activities, and on occasion understood as equivalent just to individual freedom. Interestingly, in Jesús de Nazaret, the community organisation and collective engagement exceeded by far the formal instances of participation included in the DS49 official procedurals. This is due to the long history of consolidation of housing committees for more than ten years, which included a process of saving money, legal constitution and negotiations led by dirigentes. This process certainly enriched their capabilities as a political community, and this is reflected in the scope of their achievements. It is, however, important not to romanticise the process, and to recognise a few elements that diminished its political effects. Dirigentes are still very much attached to the clientelist networks described above, and the official processes of participatory design did not necessarily transfer decision-making power to the residents.

For the Second Opportunity, participation was mainly understood as the exercise of individual freedoms, and organisation as the coordination of those individuals willing to take part rather than the construction of a collective project. Having the voucher as the main instrument of operation appealed to the individual freedom of households, but implied that the programme did not have any legal instruments to look after the families and their destination. The fact that a significant proportion of the beneficiaries stayed within BdM shows that it would have been valuable to approach housing solutions - and indeed the whole process - from a more collective standpoint.

It is very difficult for a housing programme to trigger deep social organisation, capabilities and transformation towards redistribution of power if it is attached to an understanding of housing as static units (reducing the problem to voucher assignation), rather than as a dynamic process with citywide consequences. Jesús de Nazaret is an example of a neighbourhood that was built as a result of a very complex process and multiple trajectories that came together. One of the main successes of Jesús de Nazaret is that, even if it relies on individual vouchers, it was able to build a common solution for groups of people who worked in coordination for years. But even if the 12 Exceptionally, some cases would accept 85 per cent of adherence, being a “conditioned application” (MINVU,
2013). 
notion of process is key, the scale of it is still very limited. As discussed, the kind of city that the DS49 has built remains functionally and socially homogenous, without delivering new infrastructure or challenging the current exclusion of the BdM area from the rest of the city. For the Second Opportunity, even if according to various professionals the programme had been conceived as an urban policy prior to its implementation, the political timing and the lack of appropriate legal instruments ended up reducing its scope, overlooking urban aspects and restricting its action to the provision of 'housing solutions' crystallised in a voucher.

Contrary to the economic and social dimensions, political inequality was relatively absent from interviews with government officials and does not seem to be considered as an explicit goal. The idea of participation as subordinated to freedom is deeply embedded in Chilean policies, following the key influence of the work of Friedrich Hayek in the design of Chilean current political order, and his views on democracy as secondary to individual liberty (Mouffe, 2018). Even if the idea of participation and social support is present and important before and during the houses construction, it is restricted just to some particular aspects and timeframeworks and is weakened by clientelist logics. The urban concentration of precariousness in an enclosed territory sustains political dynamics that deepen these practices, limiting the capacities of self-determination of citizens, and dominating the political trajectory of the territory.

\section{Towards housing as urbanism: Identifying the cracks}

This section presents a reflection about the main elements observed as common trends in the three dimensions, to identify the key obstacles that the programmes have faced and point out some cracks for possible transformation in the approach to policies. These elements are presented as 'a 'moment of opportunity', a 'crack' in the power relations, a situation of contradiction and conflict' (Healey, 2006, p.269), which can encourage change. These five cracks might be very general, but they constitute an effort to draw lessons from the cases that were studied. They refer to the main shortcomings of the Chilean housing model, looking to contribute to the global challenge of conceiving housing policies beyond their financial success.

(1) Institutional order, sectoral agendas, fragmentation and targeting. A first challenge identified relates to the sectoral structure of the state, in which different units struggle to work together and collaborate, with fragmented and disconnected procedures. This translates into miscommunication and differences of expectation between officials who work in central offices and those who are on the ground in the territory, or between those working on different issues such as transport or public space. On top of the fragmentation, the institutional order with a strict focus on vouchers and targeting policies creates a perverse process of segregation through 
the development of services 'for the poor' and 'for the rich' as two separate systems, with an absence of a universalist perspective in urban policies (Cociña, 2018), hindering the capacity of the policies to pursue integrative actions, beyond the city of the poor and its limits.

(2) Individual choices vs. collective processes. A policy based on the provision of subsidies and which fosters individual choice as a way of exercising freedom makes it difficult to enlarge collective processes, which are the basis of increasing the productive capacities of territories, reinforcing the role of public goods and fostering the collective political capabilities of communities. Strengthening the idea of individuals as autonomous actors reinforces fake dichotomies about the reality in the territory, hindering the existence of complex networks of collaboration, assistance, friendship, dispute and mutual respect, within organisations of various natures.

(3) Clientelism and dependency. Networks of assistance play a key role in providing social and economic support in vulnerable territories. This research has found, however, that these networks and their clientelist logic can have much deeper effects in the kind of political community built in the territory, and the capacity of it to determine its own fate. Even if the spatial concentration of the urban poor has been widely studied in Chile, clientelism has been relatively absent from the urban debate. It is the urban logic, the shortcomings and multiple vulnerabilities that allow these hierarchical logics of dependency to flourish and perpetuate. As these clientelist networks have been fed by the concentration of poverty in clearly delimited territories, they bring about solutions to problem but seldom attack the roots of concentrated urban poverty.

(4) Design as a transformative tool. An element that seems cross-cutting to all challenges, is the idea that urban design could be used as a transformative tool, strengthening local livelihoods, increasing the access to services and dealing with the challenges of inhabiting dense urban areas. Both urbanism and design as disciplines have the potential to address part of the inequalities discussed, but they do not necessarily do so innately, and therefore there is a need to put them in conversation with the different topics debated so far. The over-financialisation of housing policies and the lack of a culture of design in public institutions partly explains this.

(5) The problem of scale: Land policy and citywide processes. The final issue is the question about the scale of housing policies, their relationship to land policies and to citywide long-term processes. The voucher, sectoral and targeting logics, the institutional fragmentation and the lack of more complex instruments are important barriers in addressing these issues. Also, the urgent need to attend short-term matters, frequently precludes authorities from addressing questions that 
physically exceed the size of the housing plot or neighbourhood, and the temporal scope of specific interventions.

\section{The potentials of housing as urbanism: A final critical reflection}

Through this article, we have discussed the potential role of housing policies in reducing inequalities, exploring the ways in which a comprehensive understanding of housing as urbanism can be a useful analytical tool to approach urban equality: the potentials of housing as a productivity trigger and an asset, as a platform to the city at multiple scales, and as a collective and multidimensional process.

To conclude, we want to critically reflect on the utility and potential applications of the framework discussed. Unpacking the content and local manifestations of inequalities and discussing the potential impact of sectorial policies such as housing on them, is crucial. A framework like the one discussed here has of course a series of limitations: the division between economic, social and political aspects is analytically useful, but the constellations of inequalities are intertwined in reality in far more complex ways. Likewise, the territorial impacts of housing policies cannot be isolated from the effects of other socio-economic policies. Bearing these considerations in mind, a remaining challenge is to find ways to move from the analytical description to the measurement of their incidence. A pending challenge in this direction is to develop appropriate indicators and methodologies that are able to capture quantitatively these complexities, without over-simplifying territorial realities.

Finally, the question is also to what extent the cracks that this article identifies are relevant beyond Chile. The particular conditions of this case imply that the conclusions presented might be tied to its specific context: they will probably have different levels of relevance in contexts with distinctive institutions (e.g. with public rental housing schemes) or urban configurations (e.g. with predominant informal settlements). The main relevance of the findings discussed, however, lies in the fact that there is a growing global tendency towards the privatisation of housing provision, particularly in the global South. Then, looking at the consequences of the early implementation of privatisation in the Chilean case, can bring important lessons to other urban contexts.

Learning from these lessons does not mean to assume them as recipes in different contexts, but rather to understand how the equality agenda requires of translocal learning and exchanges. As what Gautam Bhan reflects, to do so we need an approach that is relational and yet specific. This means to adopt a perspective in which different peripheries can talk to each other, but in which 
also 'place matters', and it is central 'looking from rather than looking at' (Bhan et al, 2018, p.5).

Then, the materiality of inequalities experienced from a particular territory like BdM can open up learnings beyond its specificities, particularly to understand the consequences of the overprivatisation of housing provision. Repositioning the question of urbanism in the housing discussion, understanding and centring their non-housing effects at different scales, can shed light on this endeavour in different geographies and contexts.

\section{Acknowledgements}

The author would like to say thanks to Jorge Fiori and Camillo Boano for their supervision during this research. Also, to the valuable comments of the reviewers of Housing Studies. And thanks to the people who contributed to this study in Santiago from different public institutions, and especially to the residents of Bajos de Mena, who opened the door of their houses and allowed me to understand a portion of their lives, families and struggles; and through them, to grasp some of the layers of the complexities of housing in the city of Santiago. 


\section{References}

Aalbers, M. and Christophers, B. (2014) Centring Housing in Political Economy, Housing, Theory and Society, 31(4), pp. 373-394.

Arriagada, E. (2013) Clientelismo político y participación local. El rol de los dirigentes sociales en la articulación entre autoridades y ciudadanos en Santiago de Chile. Polis Online, 36.

Atisba (2010) Guetos en Chile (Santiago: Atisba Estudios y Proyectos Urbanos).

Auyero, J. (2001) Poor People's Politics. Peronist Survival Networks and the Legacy of Evita (Durham and London: Duke University Press).

Bhan, G., Srinivas, S. and Watson, V. (2018) The Routledge Companion to Planning in the Global South (Abingdon and New York: Routledge).

Blunt, A. and Dowling, R. (2006) Home (Oxford: Routledge).

Bridge, C., Flatau, P., Whelan, S., Wood, G., and Yates, J. (2003) Housing assistance and non-shelter outcomes, AHURI Final Report No. 40 (Sydney: Australian Housing and Urban Research Institute)

Burgess, R. (1992) Helping Some to Help Themselves: Third World Housing Policies and Development Strategies, in: Mathey, K. (Ed) Beyond Self-help Housing, pp. 75-91 (London: Mansell).

Cociña, C. and Boano, C. (2013). Housing and Reconstruction in Chile (2010-2012). Institutional and social transformation in post-disaster context, International Journal of Architectural Research, 7(3), pp. $57-79$.

Cociña, C. (2016) Habitar desigualdades: Políticas urbanas y el despliegue de la vida en Bajos de Mena. Documentos de trabajo PNUD-Desigualdad, No. 2016/05 (Santiago: PNUD).

Cociña, C. (2018) Urban Universalism: the debts of housing in the context of targeting policies, in: Boano, C. and Vergara, F. (Eds) Neoliberalism and Urban Development in Latin America: The Case of Santiago, pp. 71-82 (London: Routledge).

Cohen, G.A. (1989) On the currency of egalitarian justice. Ethics, 99(4), pp. 906-944.

Cohen, G.A. (2000) If you're an egalitarian, how come you're so rich? The Journal of ethics, 4(1-2), pp. 1-26.

Dahl, R. (1957) The Concept of Power, Behavioral Science, 2(3), pp. 201-215.

Ducci, M.E. (2000) Chile: The Dark Side of a Successful Housing Policy, in: Tulchin. J. S. and Garland. A. (Eds) Social development in Latin America: The politics of reform, pp. 149-173 (Boulder, CO: Lynne Rienner).

Durston, J. (2005) El clientelismo político en el campo chileno (primera parte). Ciencias Sociales Online, II(1), pp. 1-30.

Fainstein, S. (1999) Can we make the cities we want?, in: Beauregard, R. A. and Body-Gendrot, S. (Eds) The urban moment: cosmopolitan essays on the late-20th-century city, pp. 249-272 (London: Sage Publications). 
Fainstein, S. (2010) The just city (New York: Cornell University Press).

Fiori, J. and Ramírez, R. (1992) Notes on the Self-help Housing Critique: Towards a Conceptual Framework for the Analysis of Self-help Housing Policies in Developing Countries, in: Mathey, K. (Ed), Beyond Self-help Housing, pp. 23-31 (Mansell, UK).

Fiori, J. and Brandão, Z. (2010) Spatial Strategies and Urban Social Policy: Urbanism and Poverty Reduction in the Favelas of Rio de Janeiro, in: Hernández, F., Kellett P., and Allen, L.K. (Eds) Retbinking the Informal City. Critical Perspectives from Latin America, pp. 181-205 (New York/Oxford: Berghahn Books).

Fiori, J., Hisnley, H., Brandão, Z. and Amorim, L. (2014) Introduction, in: Housing as Urbanism. Minha Casa Minha Vida: Habitação Social e Intervenção Urbana. Housing and Urbanism Architectural Association Graduate School; MDU Departamento de Arquitetura e Urbanismo da Universidade Federal de Pernambuco (London: Architectural Association).

Fiori, J. (2014) Informal City: Design as Political Engagement, in: Verebes, T. (Ed), Masterplanning the adaptive city: computational urbanism in the twenty-first century, pp. 40-47 (London: Routeldge).

Fraser, N. (1995) From redistribution to recognition? Dilemmas of justice in a "post-socialist" age. New Left Review, I(212), pp. 68-93.

Frediani, A.A. (2009) The World Bank, Turner and Sen - Freedom in the urban arena. DPU Working Paper, N.136 (London: Development Planning Unit).

Frediani, A.A. (2010) Sen's Capability Approach as a framework to the practice of development. Development in Practice, 20(2), pp. 173-187.

Gilbert, A. (2002) Power, Ideology and the Washington Consensus: The Development and Spread of Chilean Housing Policy. Housing Studies, 17(2), pp. 305-324.

Gilbert, A. (2004) Helping the poor through housing subsidies: lessons from Chile, Colombia and South Africa. Habitat International, 28(1), pp. 13-40.

Goodchild, B. (2008) Homes, Cities and Neighbourboods. Planning and the Residential Landscapes of Modern Britain (Hampshire: Ashgate).

Guijt, I. and Shah, M. K. (Eds) (1998) The Myth of Community (Bradford: Intermediate Technology Publications).

Harvey, D. (1973) Social Justice and the City (London: Edward Arnold).

Harvey, D. (1982) The Limits to Capital (Oxford: Basil Blackwell).

Harvey, D. (2005) A Brief History of Neoliberalism (Oxford: Oxford University Press).

Harvey, D. (2008) The Right to the city. New left review, 35, pp. 23-40.

Healey, P. (2006) Collaborative Planning. Shaping Places in Fragmented Societies (New York: Palgrave Macmillan).

Larrañaga, O. (2016) La desigualdad a lo largo de la historia de Chile. Documentos de Trabajo PNUD-Desigualdad, No. 2019/09 (Santiago: PNUD).

Lefebvre, H. (1996) Writings on Cities. Selected, translated and introduced by Eleonore Kofman and Elizabeth Lebas (Oxford: Blackwell Publishers). 
Levy, C and Dávila, J. (2017) Planning for Mobility and Socio-Environmental Justice: The Case of Medellín, Colombia, in: Allen, A., Griffin, L. and Johnson, C. (Eds), Environmental Justice and Urban Resilience in the Global South, pp. 37-56 (New York: Palgrave MacMillan).

López R., Figueroa E., and Gutiérrez, P. (2013) La 'parte del león': nuevas estimaciones de la participación de los súper ricos en el ingreso de Chile, Serie de documentos de trabajo 379 (Santiago: Facultad de Economía y Negocios Universidad de Chile).

Madanipour, A. (2007) Social exclusion and space, in: Stout F. and LeGates, R. T. (Eds), The City Reader, pp. 158-165 (London: Routledge).

Madden, D. and Marcuse, P. (2016) In Defense of Housing. The Politics of Crisis (London-New York: Verso).

Martin, R., Moore, J., and Schindler, S. (Eds) (2015) The Art of Inequality: Architecture, Housing, and Real Estate. A provisional Report (New York: The Trustees of Columbia University).

Miessen, M. (2010) The Nightmare of Participation (Berlin: Sternberg Press).

MINVU (2013) Resolución 262 EXENTA. Available at http:/ /www.leychile.cl/Navegar?idNorma $=1048340 \& b u s c a r=$ recuperacion + condominios + socia les + segunda+oportunidad++262 (accessed 20 September 2015).

Moser, C. (1995) Urban social policy and poverty reduction, Environment and Urbanization, 7(1), pp. 160-172.

Moser, C. and Dani, A. (2008) (Eds) Assets, Livelihoods and Social Policy (Washington: The World Bank).

Mouffe, C. (2018) For a Left Populism (London and New York: Verso (London and New York: Verso).

Piketty, T. (2014) Capital in the Twenty-First Century (Cambridge: The Belknap Press of Harvard University Press).

PNUD (2017) Desiguales. Orígenes, cambios y desafíos de la brecha social en Chile (Santiago de Chile: Programa de las Naciones Unidas para el Desarrollo).

Ramírez, R. (2002) Evaluación social de políticas y programas de vivienda: Un análisis de la contribución de la vivienda a la reducción de la pobreza urbana. Revista Invi, 17(45), pp. 9-57.

Rapoport, A. (1995) A Critical Look at the Concept "Home", in: Benjamin, D. N. (Ed), The Home: Words, Interpretations, Meanings, and Environments, pp. 25-52 (Aldershot, UK: Avebury).

Rawls, J. (1971) A Theory of Justice (Cambridge, Massachusetts: Harvard University Press).

Rodríguez, A. and Sugranyes, A. (2004) El problema de vivienda de los "con techo". Revista EURE, 30(91), pp. 53-65.

Sabatini, F., Cáceres, G., and Cerda, J. (2001) Segregación residencial en las principales ciudades chilenas: Tendencias de las tres últimas décadas y posibles cursos de acción. Revista EURE, 27(82), pp. 21-42.

Salcedo, R. (2010) The Last Slum: Moving from Illegal Settlements to Subsidized Home Ownership in Chile. Urban Affairs Review, 46(1), pp. 90-118. 
Sampson, R., Morenoff, J., and Gannon-Rowley, T. (2002) Assessing Neighborhood effects: Social processes and new directions in research, Annual Review of Sociology, Vol. 28, pp. 443-478.

Sandoval, A. (2005) Villa Volcán San José. Temas Sociales 54, Boletín de SUR Corporación de Estudios Sociales y Educación. Available at

http://www.sitiosur.cl/centro_de_documentacion.php (accessed 20 June 2016).

Sen, A. (1979) Equality of What? The Tanner Lecture on Human Value, pp. 195-220. Available at http://hdrnet.org/43/1/sen80.pdf (accessed 24 November 2016).

Soja, E.W. (2010) Seeking Spatial Justice (Minneapolis: University of Minnesota Press).

Stephens, C. (1996) Healthy cities or unhealthy islands? The health and social implications of urban inequality. Environment and Urbanization, 8(2), pp. 9-30.

Stephens, C. (2012) Urban inequities; Urban rights: A conceptual analysis and review of impacts on children, and policies to address them. Journal of Urban Health, 89(3), pp. 464-485.

Stokes, S., Dunning, T., Nazareno, M., and Brusco, V. (2013) Brokers, Voters, and Clientelism. The Puzzle of Distributive Politics (Cambridge: Cambridge University Press).

Swyngedouw, E. (2011) Designing the Post-Political City and the Insurgent Polis (London: Bedford Press).

Turner, J.F.C. (1976) Housing by people: towards autonomy in building environments (London: Marion Boyars).

UN-Habitat (2003) The challenge of slums. Global report on buman settlements 2003 (London: UNHabitat).

United Nations (2017) New Urban Agenda (Quito: Habitat III Secretariat).

Wacquant, L. (2008) Urban Outcasts: A Comparative Sociology of Advanced Marginality (Cambridge: Polity Press).

Wallace, J. and Williamson, I. (2006) Building land markets. Land Use Policy, 23(2), pp. 123-135.

Wilkinson, R. and Pickett, K. (2009) Spirit Level: Why More Equal Societies Almost Always Do Better (London: Allen Lane).

Wratten, E.O. (1995) Conceptualizing urban poverty. Environment and Urbanization, 7(1), pp. $11-$ 38.

Wright, E.O. (2013) Transforming Capitalism through Real Utopias. American Sociological Review, 78(1), pp. 1-25.

Yates (2012) Housing subsidies, in Clapham, D.F., Clark, W.A.V. and Gibb, K. (Eds) The SAGE Handbook of Housing Studies, pp. 397-418 (London: SAGE publications Ltd).

Yiftachel, O. (1998) Planning and Social Control: Exploring the 'Dark Side'. Journal of Planning Literature, 12(2), pp. 395-406. 